\title{
Thermoluminescence dosimetry of rare earth doped calcium aluminate phosphors
}

\author{
K MADHUKUMAR*, K RAJENDRA BABU, K C AJITH PRASAD, J JAMES ${ }^{\dagger}$, \\ T S ELIAS ${ }^{\dagger}$, V PADMANABHAN ${ }^{\star}$ and C M K NAIR \\ Department of Physics, Mahatma Gandhi College, Thiruvananthapuram 695 004, India \\ ${ }^{\dagger}$ Regional Research Laboratory, Thiruvananthapuram 695 019, India \\ ${ }^{\ddagger}$ Regional Cancer Centre, Thiruvananthapuram 695 011, India
}

MS received 1 December 2005; revised 13 February 2006

\begin{abstract}
The thermoluminescence (TL) properties of calcium aluminate $\left(\mathrm{CaAl}_{2} \mathrm{O}_{4}\right)$ doped with different rare earth ions have been studied and their suitability for radiation dosimetry applications is discussed. It is observed that monocalcium aluminate doped with cerium is a good dosimeter having linear response up to about 4 kGy of radiation doses. Dopant concentration of $0.25 \mathrm{~mol} \%$ cerium gives maximum TL emission. The well-defined single peak observed at $295^{\circ} \mathrm{C}$ can be advantageously used for high temperature dosimetry applications.
\end{abstract}

Keywords. Photoluminescence; thermoluminescence; radiation dosimetry.

\section{Introduction}

Thermoluminescent materials are used as passive dosimeters in a wide range of radiological applications. Alkaline earth aluminate ceramics are important host materials that have been prepared and studied by several researchers for luminescence applications (Matsuzawa et al 1996). Alkaline earth aluminate belongs to the spinel group of minerals $\left(\mathrm{MAl}_{2} \mathrm{O}_{4}\right)$ (Dekkers and Woensdregt 2002) with general chemical composition, $\mathrm{AB}_{2} \mathrm{O}_{4}$, where $\mathrm{A}$ is a divalent atom such as $\mathrm{Mg}^{2+}, \mathrm{Sr}^{2+}, \mathrm{Ca}^{2+}, \mathrm{Fe}^{2+}, \mathrm{Mn}^{2+}, \mathrm{Zn}^{2+}$, and $\mathrm{B}$ is a trivalent atom such as $\mathrm{Fe}^{3+}, \mathrm{Al}^{3+}$. As the metal ions of $\mathrm{AB}_{2} \mathrm{O}_{4}$ are changed, the ionic ratios $\left(\mathrm{A}_{2}^{+} / \mathrm{B}_{3}^{+}\right)$change and the symmetry of unit cell can change. The ideal spinel crystallizes in the cubic space group $\mathrm{Fd3}^{-} \mathrm{m}$ with 8 tetrahedral $a$ sites and 16 octahedral $d$ sites (Schipper et al 1993). The usual anions are oxygens and are located on the $32 e$ sites arranged in cubic close packed layers. The unit cell contains eight molecules of $\mathrm{AB}_{2} \mathrm{O}_{4}$. In the normal spinel structure, all the divalent cations are located on tetrahedral $a$ sites, while all trivalent cations are located exclusively on octahedral $d$ sites.

Calcium aluminate crystals can also exist in monoclinic as well as orthorhombic structures (Dougill 1957). Many researchers have studied $\mathrm{CaAl}_{2} \mathrm{O}_{4}$ as an important constituent of cementitious compositions (Mohamed and Sharp 1997). Of late, the thrust is on its use as luminescent host. Several reports dealing with the luminescence studies of $\mathrm{SrAl}_{2} \mathrm{O}_{4}, \mathrm{BaAl}_{2} \mathrm{O}_{4}$ and $\mathrm{MgAl}_{2} \mathrm{O}_{4}$ are available

\footnotetext{
*Author for correspondence (madhusandh@yahoo.co.in)
}

in the literature (Jorma and Hogne 2001). However, there are very few reports dealing with the use of $\mathrm{CaAl}_{2} \mathrm{O}_{4}$ as a TL material. In this paper, we report the thermoluminescent properties of calcium aluminate doped with different rare earth ions $\left(\mathrm{CaAl}_{2} \mathrm{O}_{4}: \mathrm{RE}\right)$ to find out its suitability in dosimetry applications.

\section{Experimental}

Calcium aluminate phosphors were prepared by traditional ceramic (solid state) synthesis method. The reaction involved can be represented as

$$
\mathrm{CaCO}_{3}+\mathrm{Al}_{2} \mathrm{O}_{3} \rightarrow \mathrm{CaAl}_{2} \mathrm{O}_{4}+\mathrm{CO}_{2}
$$

Stoichiometric amounts of $\mathrm{CaCO}_{3}$ and $\mathrm{Al}_{2} \mathrm{O}_{3}$ were weighed taking into account different concentrations of the dopants. To this mixture, the required weight of rare earth oxide was added and the resultant mixture was thoroughly mixed in a wetting medium for about $2 \mathrm{~h}$. The mixture was dried in an air oven. The dry powder thus obtained was calcined at $900^{\circ} \mathrm{C}$ for $4 \mathrm{~h}$ in an electric muffle furnace. This was further heated up to $1250^{\circ} \mathrm{C}$ in a high temperature furnace and retained at that temperature for $7 \mathrm{~h}$.

Samples containing dopants, Ce, Dy and Sm, in different concentrations of $0.1,0.2,0.3,0.4$ and $0.5 \mathrm{~mol} \%$ were prepared. All samples were examined by X-ray diffraction to ascertain the phase formation.

Phosphors were given a ${ }^{60} \mathrm{Co}$ gamma dose of $1 \mathrm{~Gy}$ before recording TL spectrum. $10 \mathrm{mg}$ of irradiated powder was used for TL measurements. TL measurements were carried out 
using Nucleonix make TL reader. The PM tube employed was 9924 B type. This tube has sufficient response over a wide spectral range. Glow curves were recorded with a heating rate of $4^{\circ} \mathrm{C} / \mathrm{s}$. Photoluminescence (PL) studies were carried out to study the type of trapping centres present in the crystal lattice. Hitachi (F-4000) Fluorescence Spectrophotometer was used for PL studies.

\section{Results and discussion}

The XRD pattern obtained for $\mathrm{CaAl}_{2} \mathrm{O}_{4}$ phosphor prepared in this study is shown in figure 1. The spectrum matches with the data reported in JCPDS file No. 23-1036. It has a monoclinic structure with space group $P 21 / c$ with cell dimensions: $a=8.69800, b=8.09200, c=15.20800$ and $\alpha=90 \cdot 00, \beta=90 \cdot 14, \gamma=90 \cdot 00$. Table 1 shows a comparison of $d$ values obtained in the XRD spectrum with the standard. Figure 2 shows TL glow curves of $\mathrm{CaAl}_{2} \mathrm{O}_{4}$ doped with different $\mathrm{RE}$ ions. The undoped sample gives no TL emission. $\mathrm{CaAl}_{2} \mathrm{O}_{4}$ : Dy $(0 \cdot 1 \mathrm{~mol} \%)$ shows a sharp intense peak at $110^{\circ} \mathrm{C}$ with a minor peak at $282^{\circ} \mathrm{C}$. $\mathrm{CaAl}_{2} \mathrm{O}_{4}$ : Sm $(0.1 \mathrm{~mol} \%)$ shows a major peak at $182^{\circ} \mathrm{C}$ with a minor peak at $276^{\circ} \mathrm{C}$. $\mathrm{CaAl}_{2} \mathrm{O}_{4}$ : $\mathrm{Ce}(0 \cdot 1 \mathrm{~mol} \%)$ shows an

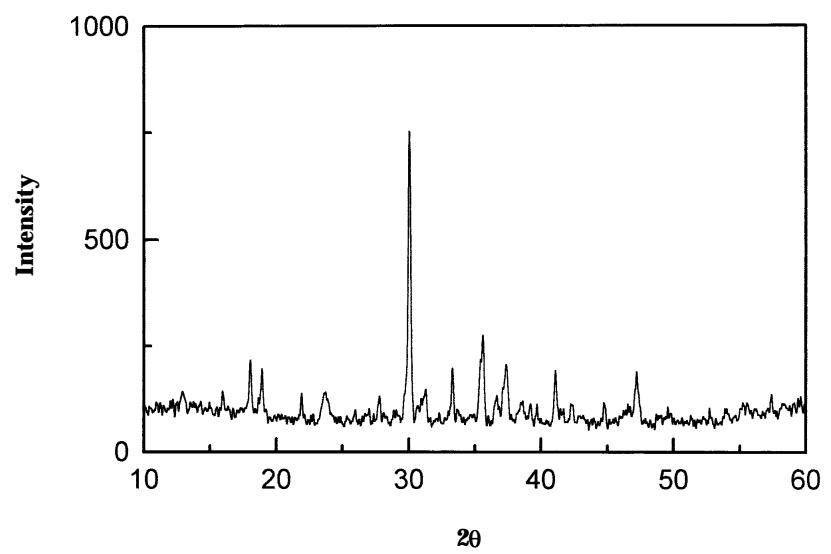

Figure 1. XRD pattern of $\mathrm{CaAl}_{2} \mathrm{O}_{4}$ phosphor.

Table 1. XRD data of $\mathrm{CaAl}_{2} \mathrm{O}_{4}$ (experimental and reported).

\begin{tabular}{rlrrrc}
\hline & $d_{\text {exptl }}$ & $I / I_{0 \text { exptl }}$ & $d_{\text {JCPDS }}$ & $I / I_{0 J C P D S}$ & $h k l$ \\
\hline 1 & $5 \cdot 535$ & 24 & $5 \cdot 530$ & 6 & 012,111 \\
2 & $4 \cdot 917 *$ & 20 & & & \\
3 & $4 \cdot 681$ & 18 & $4 \cdot 670$ & 25 & 112,112 \\
4 & $4 \cdot 052$ & 10 & $4 \cdot 040$ & 10 & 020 \\
5 & $3 \cdot 763$ & 13 & $3 \cdot 710$ & 16 & 211,211 \\
6 & $3 \cdot 208$ & 8 & $3 \cdot 200$ & 10 & 114,114 \\
7 & $2 \cdot 973$ & 100 & $2 \cdot 971$ & 100 & 123,123 \\
8 & $2 \cdot 860$ & 4 & $2 \cdot 859$ & 2 & 204 \\
9 & $2 \cdot 684$ & 21 & $2 \cdot 682$ & 2 & 311 \\
10 & $2 \cdot 521$ & 43 & $2 \cdot 518$ & 35 & 303 \\
11 & $2 \cdot 403$ & 19 & $2 \cdot 399$ & 25 & 313 \\
12 & $2 \cdot 195$ & 18 & $2 \cdot 194$ & 10 & 206 \\
13 & $1 \cdot 924$ & 18 & 1.914 & 10 & 420 \\
\hline
\end{tabular}

*Not identified. intense well defined peak at $295^{\circ} \mathrm{C}$. It is observed that TL intensity of Ce doped phosphor is very high compared to Dy and Sm doped phosphors. The sensitivity of Ce doped phosphor is nearly thrice as that of Dy and Sm doped ones. The peak observed at $110^{\circ} \mathrm{C}$ for Dy doped one is not good for dosimetry applications as its fading rate will be very high. Also the major peak at $182^{\circ} \mathrm{C}$ observed for $\mathrm{Sm}$ doped phosphor is also not good enough for dosimetric applications due to its low intensity. The well-defined single peak obtained at $295^{\circ} \mathrm{C}$ in the case of $\mathrm{Ce}$ doped phosphor can be used for dosimetry applications. It is seen that $0.25 \mathrm{~mol} \%$ of Ce gives maximum TL emission (table 2).

\subsection{Photoluminescence studies}

The photoluminescence studies were carried out only on Ce doped phosphors since it was observed that only $\mathrm{Ce}$ doped phosphor satisfies the essential requirements of a good TL dosimeter. The excitation spectrum of $\mathrm{CaAl}_{2} \mathrm{O}_{4}$ : Ce $(0.1 \mathrm{~mol} \%)$ scanned for emission wavelength, $350 \mathrm{~nm}$, is shown in figure 3 . The bands observed at 300 and $315 \mathrm{~nm}$ are assigned to the transitions from $4 f$ to the lowest Stark level of $5 d$ state of $\mathrm{Ce}^{3+}$ ions (Kutty 1990). The

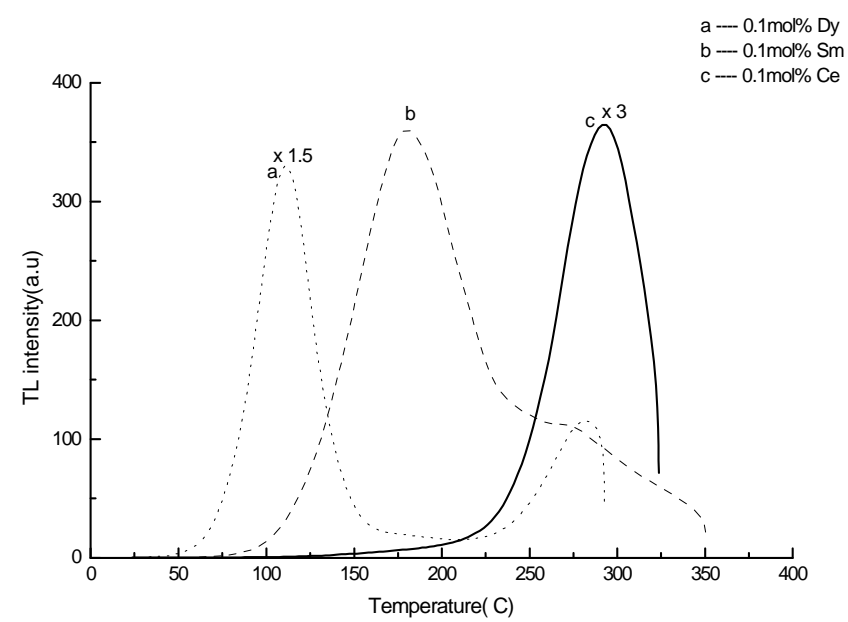

Figure 2. TL glow curves of a. $\mathrm{CaAl}_{2} \mathrm{O}_{4}: \mathrm{Dy}$, b. $\mathrm{CaAl}_{2} \mathrm{O}_{4}: \mathrm{Sm}$ and c. $\mathrm{CaAl}_{2} \mathrm{O}_{4}: \mathrm{Ce}(0 \cdot 1 \mathrm{~mol} \%$ each). Dose $1 \mathrm{kGy}$.

Table 2. TL intensity of $\mathrm{CaAl}_{2} \mathrm{O}_{4}$ : Ce phosphor with variation in Ce concentration.

\begin{tabular}{lc}
\hline Ce concentration $(\mathrm{mol} \%)$ & $\begin{array}{c}\text { Relative TL intensity } \\
\left.\text { (peak height) (peak at } 295^{\circ} \mathrm{C}\right)\end{array}$ \\
\hline $0 \cdot 05$ & 0.34 \\
$0 \cdot 10$ & 0.45 \\
$0 \cdot 15$ & 0.52 \\
$0 \cdot 20$ & 0.63 \\
0.25 & 1.00 \\
0.30 & 0.83 \\
0.35 & 0.68 \\
0.40 & 0.55 \\
0.50 & 0.43 \\
\hline
\end{tabular}


multi-peaks observed in the excitation spectrum indicate that different defect related traps are present in the crystal lattice. The defect related trapping centres could be filled by either electron transport through conduction band or by tunneling through $5 d$ states. Figure 4 shows the emission spectrum of $\mathrm{CaAl}_{2} \mathrm{O}_{4}$ : Ce obtained for an excitation wavelength, $315 \mathrm{~nm}$. A broad emission band ranging from 330$350 \mathrm{~nm}$ together with a weak band at $467 \mathrm{~nm}$ is seen. The broad emission of $\mathrm{Ce}^{3+}$ ions is due to $5 d-4 f$ transitions in nature in which the $5 d$ orbital is not well shielded from the crystal field as the $4 f$ orbital is, because the $5 d$ orbital is situated further away from $4 f$. The luminescence of $\mathrm{Ce}^{3+}$ is very intense since the transitions involved are parity allowed (Claude 1984). These transitions take place from the excited states to the ${ }^{2} F_{5 / 2}$ and ${ }^{2} F_{7 / 2}$ ground states of $\mathrm{Ce}^{3+}$ ions.

\subsection{Effect of radiation dose on TL intensity}

Figure 5 shows TL response of $\mathrm{CaAl}_{2} \mathrm{O}_{4}$ : Ce $(0 \cdot 1 \mathrm{~mol} \%)$ irradiated with different doses of $\gamma$-radiations. The height

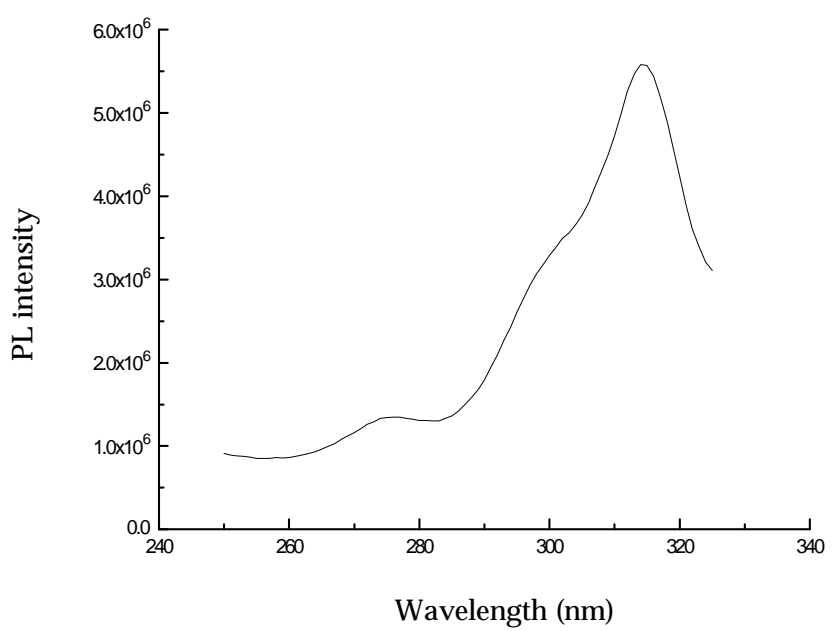

Figure 3. Excitation spectrum of $\mathrm{CaAl}_{2} \mathrm{O}_{4}: \mathrm{Ce}(0 \cdot 1 \mathrm{~mol} \%)$ $\left(\lambda_{\mathrm{em}}=350 \mathrm{~nm}\right)$.

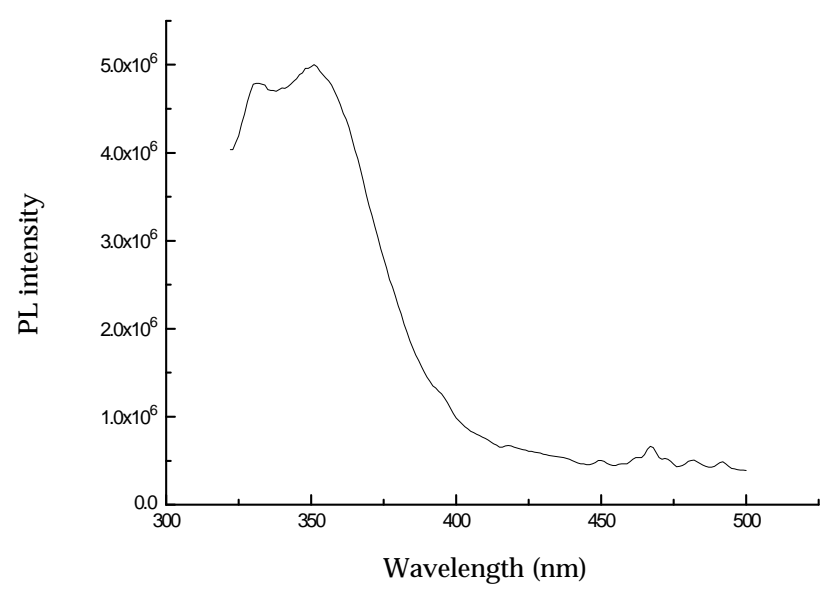

Figure 4. Emission spectrum of $\mathrm{CaAl}_{2} \mathrm{O}_{4}: \mathrm{Ce}(0 \cdot 1 \mathrm{~mol} \%)$. $\left(\lambda_{\mathrm{ex}}=315 \mathrm{~nm}\right)$. of $295^{\circ} \mathrm{C}$ peak is plotted as a function of exposure. It is seen that the TL response of the phosphor is almost linear for low doses and tending to saturate at higher doses above $4 \mathrm{kGy}$. Hence this phosphor can be used for dose measurements up to $4 \mathrm{kGy}$.

\subsection{Fading}

Figure 6 shows the variation of TL response with storage duration of irradiated $\mathrm{CaAl}_{2} \mathrm{O}_{4}: \mathrm{Ce}(0 \cdot 1 \mathrm{~mol} \%)$ phosphor. Periodic checking of TL response shows $5 \%$ fading of $295^{\circ} \mathrm{C}$ peak over a period of two weeks. This is well within the accepted rate of fading of standard TL phosphor (Nambi 1977; Mckeever 1985).

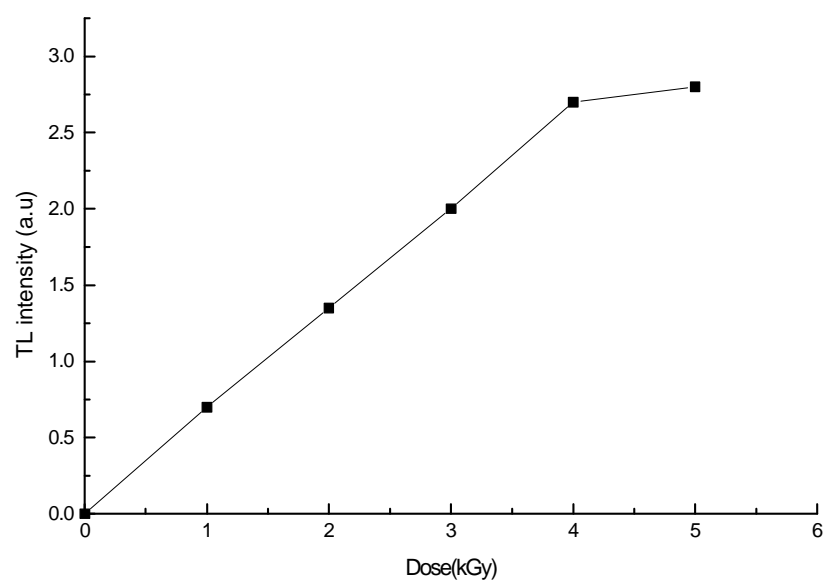

Figure 5. Dose response curve of $\mathrm{CaAl}_{2} \mathrm{O}_{4}: \mathrm{Ce}(0 \cdot 1 \mathrm{~mol} \%)$.

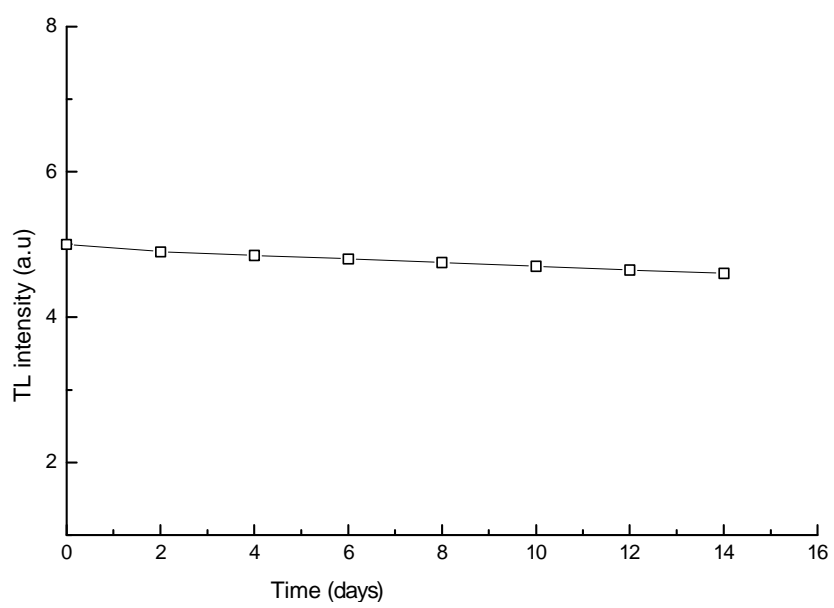

Figure 6. Fading characteristic of $\mathrm{CaAl}_{2} \mathrm{O}_{4}: \mathrm{Ce}(0 \cdot 1 \mathrm{~mol} \%)$.

Table 3. Comparison of TL response.

\begin{tabular}{lcc}
\hline Phosphor & $\begin{array}{r}\text { Most intense TL peak } \\
\text { temperature }\left({ }^{\circ} \mathrm{C}\right)\end{array}$ & $\begin{array}{c}\text { Relative TL } \\
\text { intensity }\end{array}$ \\
\hline $\mathrm{CaSO}_{4}: \mathrm{Dy}$ & 230 & 1 \\
$\mathrm{CaAl}_{2} \mathrm{O}_{4}: \mathrm{Ce}$ & 295 & 0.5 \\
\hline
\end{tabular}




\subsection{Sensitivity}

Table 3 gives a comparison of TL response of $\mathrm{CaAl}_{2} \mathrm{O}_{4}$ : $\mathrm{Ce}$ phosphor with the standard one $\left(\mathrm{CaSO}_{4}\right.$ : Dy) used for radiation dosimetry applications. It is observed that the sensitivity of $\mathrm{CaAl}_{2} \mathrm{O}_{4}$ : Ce phosphor is only $50 \%$ as that of $\mathrm{CaSO}_{4}$ : Dy, when both were exposed to same dose of radiation.

\section{Conclusions}

From the PL and TL studies it is confirmed that $\mathrm{Ce}^{3+}$ doped $\mathrm{CaAl}_{2} \mathrm{O}_{4}$ is a good material for dosimetry applications. The emission centres are $\mathrm{Ce}^{3+}$ ions. The fading rate is very small and its TL response is linear up to radiation dose of $4 \mathrm{kGy}$. Though TL sensitivity of $\mathrm{Ce}^{3+}$ doped $\mathrm{CaAl}_{2} \mathrm{O}_{4}$ is less when compared to the widely used $\mathrm{CaSO}_{4}$ : Dy commercial phosphor, it should be noted that the $295^{\circ} \mathrm{C}$ peak observed in $\mathrm{CaAl}_{2} \mathrm{O}_{4}$ : $\mathrm{Ce}$ can be used for high temperature dosimetry applications with more advantage (TL peak of $\mathrm{CaSO}_{4}$ : Dy is at about $230^{\circ} \mathrm{C}$ only).

\section{Acknowledgements}

The authors are thankful to Dr K S V Nambi, Former HoD, Environmental Assessment Division, BARC, Mumbai, for giving valuable suggestions during the course of this work. The authors also thank Dr H K Varma, Dr Manoj Komath and their colleagues in the Bioceramics Division, Sree Chitra Tirunal Institute for Medical Sciences and Technology, Thiruvananthapuram, for providing laboratory facilities to carry out this work. The financial assistance provided by KSCSTE, Govt. of Kerala, for this work is gratefully acknowledged.

\section{References}

Claude F 1984 Luminescence-encyclopedia of inorganic chemistry (New York: Academic Press)

Dekkers R and Woensdregt C F 2002 J. Cryst. Growth 236 441

Dougill M M 1957 Nature 180292

Jorma H and Hogne J 2001 J. Alloys Compounds 323-324 326

Kutty T R N 1990 Mater. Res. Bull. 25485

Matsuzawa T, Aokiy Y, Takeuchi N and Murayama Y 1996 J. Electrochem. Soc. 1432670

Mckeever S W S 1985 Thermoluminescence of solids (Cambridge University Press)

Mohamed B M and Sharp J H 1997 J. Mater. Chem. 71595

Nambi K S V 1977 Thermoluminescence: Its understanding and applications (Sao Paulo, Brazil: IEA Informacao)

Schipper W J, Hamelink J J, Langeveld E M and Blasse G 1993 J. Phys. D: Appl. Phys. 261487 